\title{
THE PROBLEM OF THE EU IN REACHING AND MAINTAINING A COMMON POSITION IN INTERNATIONAL TRADE NEGOTIATIONS
}

\section{Yonca Özer*}

\begin{abstract}
Common international trade policy of the European Union has suffered delays and difficulties due to the diversified commercial interests and individual trade policies of the Member States. Reaching and maintaining a common position in international trade negotiations has therefore proved to be a cumbersome procedure for the Community institutions, especially in the recent example of the Uruguay Round of the General Agreement of Tariffs and Trade (GATT).

This work examines the way the EU can reach and maintain, in the most successful way, internal cohesion within the Community, so that a common trade policy can be exercised against third countries by overcoming the detrimental effects of geographical, economic and social diversity of the Member States.

The theoretical approach adopted in the analysis of the subject is the twolevel bargaining model which depends on the interaction between the international institutional level and the domestic level, taking into account both the Member States as central players, as well as the initiatives of the EU institutions and the intergovernmental bargaining between the Member States.
\end{abstract}

\section{Introduction}

Because of the differences between the Member States (MSs) on international trade policy, the European Community (EC) experienced a difficult process of reaching internal consensus in the Uruguay Round (UR) negotiations. This situation both delayed and jeopardised the conclusion of the multilateral negotiations.

The European Union's (EU) trade policy has to square the commercial interests of all MSs to each other to be able to constitute an integrated, coherent whole. Both for a strong bargaining position against third countries in international

* Research Assistant, Marmara University, European Community Institute. 
negotiations and for a successful conclusion of negotiations, reaching and maintaining internal cohesion within the EU is essential. However, because of geographical, economic and social diversity within the EU, which is, of course, characteristic of any country of continental size, to attain internal cohesion is far from an easy task. Thus, common trade policy making is a complex process of depending on the creation of consensus among an expanding group of members whose competitive structures and policies differ considerably.

The aim of this study is to examine how the EU reaches and maintains its common position in international trade negotiations. By refering to the UR, which was the last multilateral trade negotiations under the auspices of the GATT (General Agreement on Tariffs and Trade), it tries to address how the EU can reach internal cohesion in such international trade negotiations through its unique institutional structure.

The EU's common negotiating position in international trade negotiations is formed through its trade policy making procedure. A complete and satisfactory analysis of establishing and maintaining internal cohesion within the EU requires an emphasis on the EU's unique institutional structure. The study starts with a chapter analysing this procedure and the EU structure.

The following chapter addresses the weaknesses of the intergovernmentalist approach and incorporates an extended view of the two-level approach into discussion. The argument of this chapter is as follows. Since the power of decision is in the hands of the Council, at a first glance the making of trade policy in the EU may be explained by the intergovernmentalist view. However, an intergovernmentalist analysis, which adds international institutional structure to the domestic policy making in a process taking place in successive stages, creates a separation between the levels of analysis. Therefore, in order to explain the EU trade policy making satisfactorily, it is essential to adopt a more integrated theoretical approach incorporating both domestic and international institutional levels in the policy making process as well as the interaction between these levels. It should be noted that although the MSs are the central players in the EU's policy making, initiatives of the EU institutions as well as an intergovernmental bargaining between the MSs shape the EU trade policy. Thus, the two-level bargaining model which depends on the interaction between the international and domestic levels has to be extended to take into account the unique institutional structure of the EU instead of a pure intergovernmental model.

This chapter addresses this necessity and concentrates on two-level games approach to be able to find a satisfactory answer to how the EU reaches and maintains a common position in international trade negotiations. International 
trade negotiations with third countries, as in the UR, constituted a good example of two-level games approach. On the one hand, the Union negotiators bargain with the other negotiating partners to have, at the end, a tentative agreement. On the other hand, the Union needs to maintain its internal cohesion during the international negotiations to get the agreement approved by the EU's decision-making structures. Because of the interaction between these two levels, maintaining internal consensus in the EU primarily depends on satisfactory and, therefore, acceptable evolution of the international negotiations for all MSs. Since the Commission, as the EU's chief negotiator, restructures the bargaining situations and facilitates arrangements which can secure an international agreement while assuring its ratification in the Council, its role in reaching and maintaining a common position in international trade negotiations is primordial. In the case of a break up of internal consensus as a result of unsatisfactory developments in international negotiations for one or more MSs, the Commission initiates some arrangements like side-payments or issue-linkages to persuade these MSs for the sake of reaching internal consensus, which is necessary to secure the conclusion of the international agreement.

The last chapter includes a case study to support what is argued in the previous chapter. Since it was one of the two most controversial issues in the UR negotiations regarding reaching and maintaining an internal consensus, textiles and clothing issue was choosen as a case study to examine how a common position could be reached in this sector.

\section{Trade Policy Making Procedure in the EU and the Role of the Institutions}

The EU trade policy is made within the framework of a written constitution laid down in the founding treaties. The Treaty of Rome sets out the procedure for setting EU trade policy, in other words, to be followed in the negotiation and conclusion of international trade agreements involving the EU.

Three EU bodies, namely the Council of Ministers, the European Commission and the European Parliament, are most involved in the EU trade policy-making. These institutions and subordinate bodies of the Council which are Committee of Permanent Representatives (COREPER) and the Article 113 Committee, as well as a number of pressure groups, which operate on national and European levels and represent consumer and producer groups across the MSs, are the main players in the trade policy-making process in the EC. Through its landmark decision especially on the competence of the European Commission to negotiate on behalf of the MSs on "new issues", the European Court of Justice (ECJ) has also become involved in the trade policy-making process at the request of the Commission. 


\section{1. The Negotiating Mandate}

Articles $110-116$ of the Rome Treaty had established a clear competence for the EU in implementing a common commercial policy, and the key provisions for the Common Commercial Policy (CCP) regarding trade agreements are found in Article 113. Pursuant to Article 113, European Commission drafts proposals for negotiations for approval by the Council. These proposals are then discussed in the Committee for Permanent Representatives (COREPER). On the basis of these discussions, the Council approves a negotiating mandate, by a qualified majority authorising the Commission to enter into negotiations. The Commission may request additional negotiating mandates from the Council.

The European Commission is the EU's central executive body, which, under the founding treaties, has powers of initiative in matters of trade policy. It also negotiates trade agreements on behalf of the EU as a whole and represents the $\mathrm{EU}$ in multilateral trade negotiations. It consists of 20 Commissioners of whom two are appointed by the governments of each of the larger EU countries and one each by the smaller member countries. Commissioners perform their duties by just taking into consideration the general interest of the EU. They are completely independent and, therefore not influenced by their national interests. In other words, when they perform their duties, they do not seek or accept instructions from any Government (Article 157 of the Rome Treaty).

While the Commission represents the EU's interests as general, the Council represents the aims, interests and priorities of individual MSs. This difference between the Council and the Commission may sometimes lead to conflicts between them. The Council of Ministers has the authority to approve Commission proposals. Since a measure of the considerable power in the hands of the Council within the trade policy framework is that it can change or reject a Commission proposal through a qualified majority vote, the Commission has to take to some extent national interests into consideration.

The Council of Ministers consists of ministers from each member government. The national ministers will be determined by the subject under discussion. Therefore, the Council of Ministers meets under different titles as Agriculture, Finance, Social Affairs, and General Affairs. Since there is no regularly convened special Council of Trade Ministers, discussions on trade policy have usually been on the agenda of the General Affairs Council formed by the Ministers for Foreign Affairs. Other Councils play a role in international trade negotiations as well like the Agricultural Council in the UR negotiations.

The Council's proposals are discussed by the Committee of the Permanent Representatives to the EU (COREPER) which is responsible for preparing the 
work of the Council before they are submitted to the Council. COREPER, which is more concerned with the political aspects of trade issues, meets at the levels both of the national ambassadors to the EU and their deputies, together with officials from the Commission. If an EU position can be agreed by the COREPER in advance of Council meetings, the issue is adopted without discussion by the Council concerned. If the issue is too sensitive or requires a high level decision, it is put to a Council vote. ${ }^{1}$

\section{2. Issue of Competence}

When the Council decided to authorise the Commission to open the UR negotiations, it was also agreed that the Commission would act as the sole negotiator on behalf of the Community and the MSs on all issues of the UR, including issues of mixed competence in order to ensure maximum consistency in the conduct of negotiations. It was in this way that the Community and the MSs were able avoid the issue of competence during the negotiations. Therefore, the Commission negotiated for both the Community and the MSs during the whole period of the UR, although the Final Act of the UR was signed by the Community as well as the MSs as a mixed agreement. Since a single voice in trade matters is more effective, member governments accepted the need for the EC to negotiate with one voice in areas of mixed competence. Therefore, the EC had fewer problems in areas of mixed competence than in areas exclusive EC competence such as agriculture and textile. ${ }^{2}$ According to Rohini Acharya, the main problem for a number of sectors was that MSs themselves were unable to agree on a common negotiating line rather than competence becoming a point of contention between MSs and the Commission during the UR. ${ }^{3}$

In EU trade policy, the division of competence between the EU and the MSs has always been a controversial issue. The MSs have been openly reluctant to completely surrender their competence over international trade matters to the EU. Ill-defined competence of the EU in the field of international trade relations by the Rome Treaty strengthens and nourishes this reluctance. ${ }^{4}$

A ruling by the ECJ in 1971 initially gave the Community competence to enter into international trade agreements in areas where common EC rules existed or where the development of such a policy would be hindered by national action. Since the transitional period has ended on 31 December 1968, Articles 110-116 on CCP have given the EU competence in policy with regard to trade in goods, while nation-states have competence in other areas of trade policy such as services and intellectual property. ${ }^{5}$

Following a request from the Commission to overcome any potential contradiction between MSs and itself on trade policies, the ECJ made an 
important ruling on intellectual property rights and services in 1994. It ruled that on issues of non-cross-border provision of services and intellectual property rights, competence was either shared or national, rather than a Community prerogative. This ruling does not, however, make the situation less complicated because the MSs' governments can decide that they want to negotiate on the issues concerned. Since this decision had the potential to create problems in further negotiations on services in the World Trade Organisation (WTO), this issue was taken up by the Amsterdam Treaty. The Amsterdam Treaty aims to extend the competence of the Union to the key areas of intellectual property and services.

\section{3. Conduct of Negotiations}

During international trade negotiations, the Commission is the sole spokesperson and negotiator for the EU as a whole acting on the basis of the Council's negotiating mandate. Depending on the issue involved in international trade negotiation, the Commission obtains varying degrees of discretion and flexibility through the mandate. During the UR negotiations the Council sometimes thought that the Commission was stretching or even exceeding its mandate in order to reach on agreement with the other negotiating parties as in the case of negotiations on textiles and clothing.

The third paragraph of Article 113 of the Rome Treaty on the negotiation of trade agreements states that the Commission shall conduct trade negotiations with countries outside the EU in consultation with a special committee appointed by the Council to assist the Commission in this task and within the framework of such directives as the Council may issue to it. Therefore, the Commission's freedom to negotiate the international trade negotiations is circumscribed by way of negotiating directives of the Council and Article 113 Committee.

Bossche argues that although the negotiating directives issued by the Council may play an important role in international trade negotiations and allow the Commission only limited discretion, the situation for the UR was different. ${ }^{6}$ The Council did not adopt formal negotiating directives covering all aspects of these negotiations.

The Article 113 Committee, which has its name from Article 113 of the Rome Treaty and which is composed of national senior officials based in the MSs' Permanent Representations to the EU in Brussels, is the second way in which the freedom of the Commission to negotiate is restricted. During the UR, the Commission's activities were closely monitored by this Committee. It is the main contact point between the Commission and the MSs in multilateral trade negotiations. The Commission proposes a policy to the Council only after 
considerable consultation with the Article 113 Committee and within the Commission. Unless politically sensitive or significant changes to negotiating mandates are necessary, these are not referred to the Council and are confirmed by the Article 113 Committee. ${ }^{7}$ Although the role of the Article 113 Committee is only advisory and its task is not to issue binding instructions to the Commission but to assist to the latter, it plays an important role in shaping EU trade policy by establishing a link between the Commission and the MSs. Since it provides indirect and preliminary contact between the Commission and the Council, its regular interaction with the Commission ensures that the proposals submitted by the Commission are only rarely rejected by the Council. Therefore, the relationship between the Commission and the Article 113 Committee is crucial to ensure that each proposal sufficiently reflects the requirements of the MS and the Council and therefore to prevent the proposals not to be repudiated by the Council.

\section{4. Consultations during Negotiations}

The European Parliament (EP) has a limited role in trade negotiations since agreements concluded under Article 113 do not require EP approval. It is the weakest of the three institutions in the $\mathrm{EC}^{\prime} \mathrm{s}$ external trade policy formation process. In practice, however, the Commission and sometimes the Council discuss trade matters with the EP on an informal basis. A Council undertaking in 1993 ensured that it would be consulted on all important trade agreements. The EP has succeeded in obtaining increased co-operation from the Commission and the Council over the years. With respect to the UR, although the Parliament obviously monitored the negotiations carefully, and made its views known to the Council and the Commission on many issues, its influence has not been very large with regard to the conduct of the negotiations.

The consultation processes also incorporate various pressure groups representing industrial and consumer interests. Initially lobbies concentrated on putting pressure on national governments. However, their involvement at the European level has increased in recent years because of the growing importance of the Commission in European policy-making. While national lobbies continue target the Council as it adopts final decisions, the Commission has been more actively targeted by European level lobbying. Such European level lobbies provide further information for the Commission on national structures and industries in addition to being a source of pressure. ${ }^{8}$ Due to the absence of formal consultation mechanism with pressure groups on trade issues, the Commission has informal contacts. Therefore, the relationship between the Commission and these groups is unstructured, less transparent and quite adhoc. Such relationship obscures the fact that pressure groups are actively involved in trade decision-making process. 
Pressure groups commonly consider that it is more important to lobby their national government for the policies they wish to see followed in the EU than to make representations to the Commission. They may of course lobby both their national government and the Commission if their resources allow, and in particular if they can make common cause with producers in other MSs. However, European industries generally prefers to focus their lobbying efforts on their national governments rather than the Commission.

\section{5. Conclusion of Negotiations}

International trade agreements are signed by the Commission and the Presidency of the Council on behalf of the EC. In concluding the UR, the MSs also signed the Final Act as a mixed agreement since they disputed the EC's competence to conclude them.

As mentioned above, the freedom of action of the Commission is constrained by the need to secure the approval of the final trade agreement by the Council. While the Commission can conduct multilateral trade negotiations on behalf of the MSs, in the end it needs to have the agreement of the MSs in the Council on the final outcome. The Commission initiates the final trade agreement, presents it to the Council, and the Council approves the agreement under Article 115 of the Rome Treaty, which lays down that the Council shall exercise its powers in matters of trade policy by qualified majority vote. The qualified majority in the Community of twelve (during the UR negotiations) consisted of 54 votes out of a total of 76, divided among the MSs according to their economic weight: 10 votes each for Germany, France, Italy and the United Kingdom, 8 votes for Spain 5 votes each for Belgium, Greece, the Netherlands and Portugal, 3 votes each for Denmark and Ireland and 2 votes for Luxembourg. Since the accession of Austria, Finland and Sweden on 1 January 1995, the qualified majority requires 62 votes out of 87 . This total results from the addition to the previous allocation, which remains unchanged, of 4 votes for Austria and Sweden and of 3 votes for Finland. That the Council votes on trade issues by means of qualified majority means that the system allows a small group of countries to form a blocking minority whose votes are more than 25 and also that a small group of countries whose votes are less than 25 can be overruled by a majority coalition.

On trade policy matters there are typically blocking minorities of liberals and of protectionists. Attempts to categorise free traders and protectionists among the MSs can be misleading since it changes from sector to sector. For example, France is more protectionist with respect to agriculture but supports the liberalisation of international trade in services, and Ireland has a liberal approach for investment issue but has protectionist approach with respect to agriculture. Therefore, there are no clear-cut categories. However, in general 
while the Netherlands, Germany, Denmark, Sweden, Finland, Austria, the UK and in some respects Ireland are most supportive of multilateral trade liberalisation, the southern MSs (France, Italy, Greece, Spain, Portugal) and Belgium are more protectionist and on the defensive side. Therefore, decisions on the whole depend on the attitude of the median group, issue by issue. ${ }^{9}$ Although at the beginning of the 1980s the EC was defensive and reactive, it has gradually become more liberal, more supportive of multilateral approaches and pro-active because of the liberalisation of internal policies.

Despite the disentanglement of blocking minorities, on matters considered to be of vital national importance, a country may be able to exercise a veto. This means that a MS has a power of veto if it declares that a very important national interest is involved and at stake. This power was given to the MSs by the Luxembourg Compromise, which was agreed by the original six MSs in January 1966 to bring to an end President de Gaulle's boycott of the Council (empty chair case).

\section{Explanation of Reaching Common Trade Policy by the EU in International Trade Negotiations}

Foreign policy making is explained by domestic and international factors. International explanations assume that nation states are unitary actors and their foreign policy is determined according to external incentives and changing external constraints. However, domestic explanations locate the determinants of foreign policy and international relations within the nation state itself. In this view, foreign policies, like internal policies, are subject to domestic debate and deliberation. While domestic explanations have ignored the importance of external factors as the determinants of the foreign policy, international explanations have ignored the influence of domestic factors on foreign policy making. To be able to get rid of such ignorance on both side with respect to the other side and, therefore, to provide a coherent and sufficient explanation of foreign policy determination, empirical studies formulated at a single level of analysis, international or domestic, are increasingly being supplanted by efforts to integrate the two. As a theory of international bargaining, two-level games approach, which presents a framework for analysing the combined leverage of domestic and international factors on determination of foreign policy stance in international negotiations, is one of the most satisfactory efforts to integrate international and domestic level of analysis.

\section{1. Two-level games Approach}

In international relations theory, Robert Putnam's approach towards understanding international bargains has gained a lot of attention, and it has 
also led the way for much of the recent theorising about the EU. Recognising that domestic politics and international relations are entangled, Putnam conceives the politics of international negotiations as constituting a two-level games where the state acts at the two levels simultaneously, the domestic and international level: "At the national level, domestic groups pursue their interests by pressuring the government to adopt favourable policies, and politicians seek power by constructing coalitions between those groups. At the international level, national governments seek to maximise their own ability to satisfy domestic pressures, while minimising the adverse consequences of foreign developments."10

In international negotiations, negotiators representing their governments are subject to the constraint that any tentative agreement as a conclusion of these negotiations must be ratified by their respective governments. Each government is represented by a single leader or chief negotiator. This individual cannot pursue independent policy preferences. He just seeks to achieve an agreement that will be acceptable to his constituents. ${ }^{11}$ As it was mentioned in the previous chapter, although it is under the competence of the Commission to conduct international trade negotiations on behalf of the EU, the freedom of action of the Commission is constrained by the need to secure the agreement of the Council on the final outcome of the negotiations. Even though qualified majority vote is sufficient for Council's approval of the final outcome, existence of right of veto necessitates a consensus between the MSs on the final agreement. Additionally, in the case of the UR, the MSs agreed that the Council would make the political decision to approve the Round by consensus since in view of the economic and political significance of the Round it did not seem appropriate to approve the Round's Final Act against the will of one of the partners. Therefore, the Community needed to maintain a high degree of internal cohesion during the negotiations to get the agreement approved by the EC's decision-making structures.

In two-level games theory, the chief negotiators are strategically positioned between two tables. In other words, they appear simultaneously at two different game tables, one representing domestic politics and the other international negotiation. Each chief negotiator must try to find a successful and consistent strategy at both tables simultaneously. This makes this two-level games very complicated for the chief negotiator who is forced to balance and integrate domestic and international concerns. Putnam states that since foreign policy in this view is not constituency driven, but it is constituency constrained, the chief negotiator acts with some degree of autonomy. ${ }^{12}$ Therefore, the two-level games approach is not a purely "bottom-up" theory of the domestic roots of foreign policy. 
While Moravcsik evaluates two-level games approach, he points out that the chief negotiator's strategies reflect a simultaneous "double edged" calculations of constraints and opportunities on both the domestic and international tables. ${ }^{13}$ Domestic policies can be used to affect the outcomes of international bargaining, and international moves may be solely aimed at achieving domestic goals. According to Moravcsik, this differentiates the model from additive approaches in which domestic interests and international bargaining are treated as superimposed. Its typology and analysis, of strategies for simultaneously exploiting both levels in a bargaining situation is a distinctive element in the two-level games approach. Since expectations and unfolding developments in one arena affect negotiations in the other arena, the international and domestic phases are intertwined and simultaneous. Moravcsik terms this sort of analysis an "interactive approach" because of its stress on the interaction between the two levels.

Normally, there are prior consultations and bargaining at domestic level to hammer out an initial position for the negotiations at international level. However, this initial position may change and the constituents' views may themselves evolve in the course of the negotiations. In the context of this fact, the negotiators try out possible agreements and probe their constituents' views. Therefore, the two-level process may be "iterative".

Since the chief negotiator needs the ratification of the domestic constituents to conclude the international negotiations, he pursues some strategies to secure the domestic ratification of the final agreement of the negotiations. The chief negotiator can act autonomously if he negotiates with his colleagues within his domestic "win-set" defined as the set of potential agreements that would be ratified by domestic constituencies in a straight up-or-down vote against the status quo of no agreement. Therefore, he is not confronted with domestic constraints depending on group calculations of interests and their political influence. However, if the evolution of the negotiations do not provide the chief negotiator a sufficient latitude to act autonomously within the domestic win-set, he will have to adopt strategies to expand the domestic win-set (Cutting Slack) to secure the ratification of the international agreement that might otherwise be rejected. The most fundamental constraint on the chief negotiator is the size of the win-set. If the benefits of an agreement or the costs of noagreement increase, the win-set expands as well. ${ }^{14}$

The chief negotiator may expand the domestic win-set and, therefore, alter the outcome of the ratification process through synergistic issue linkage, selective mobilisation of political groups, manipulation of information about the agreement or side-payments. Implementing a broad program of social or institutional reform is the most radical method of altering domestic constraints. 
The greater the chief negotiator's control over these instruments, and the lower the cost of exercising such control, the greater his or her ability to shape the final agreement. ${ }^{15}$

Some factors may have a direct effect on the ability of the chief negotiator to manipulate domestic constraints and to act independently. First is the concentration of domestic groups. Concentrated groups that are disadvantaged by an agreement will become both intransigent and influential opponents of agreement. However, the more diffuse the costs of the proposed agreement, the more possibilities for the chief negotiator to gain swing groups' support at relatively low cost. Second, uncertainty about the content of agreement may increase the ability of a chief negotiator to manipulate domestic perceptions by selectively releasing information. In cases where gains and losses are clear and certain, tangible side-payments would probably be necessary. Third, the flexibility of the institutions through which ratification takes place can be decisive since the more restrictive the ratification procedure, the less autonomy is left to the chief negotiator. ${ }^{16}$

\section{2. Three-level games for the EU in International Trade Negotiations}

In the case of EU, the game in the international trade negotiations not only takes place between two levels but also between three levels since the EU is not a unitary state but a unique supranational actor based on the principle of delegation of sovereignty by fifteen states to some extent: "At the first, the global level, the EU negotiates with other states. At the second, the EU level, representatives of the MSs negotiate with one another to determine the EU's stance in the global negotiations. At the third, the national level, national leaders negotiate to determine their position in the EU level negotiations." 17

Because of the interaction between these separate three levels during the international trade negotiations and because of the EC's unique institutional trade policy making procedure, determination of a common trade policy in the negotiations is quite complicated and difficult. Since the Commission needs an agreed position when it negotiates on behalf of the EU, prior consultations and bargaining at EU level take place to hammer out an initial common position for the negotiations at international level. However, this initial consensus between the MSs may not be maintained throughout the negotiations because of their unsatisfactory evolution for some MSs.

All MSs act within the limits of their domestic win-sets. They are all constrained by domestic interests. Their governments are pushed by the desire of maintaining support and of being re-elected. In addition to desire to promote the public interest, desire to bolster their positions by being seen to be active 
has been a significant driving force. Therefore, if there is an unsatisfactory development in the international trade negotiations in terms of relevant domestic interest of a MS or more, then it or they may take a different position compared to the other MS's. This blocks the consensus within the EU and, therefore, jeopardises the conclusion of the negotiations.

In this case, the Commission plays a crucial role in providing internal cohesion, and therefore, in securing the conclusion of the negotiations by acting simultaneously at all three levels. Both the EU in general and the MSs specifically have their own respective win-sets. All MSs do not have the same size of winset since they differ from each other in terms of interests and ideas. At the beginning of the UR, they could find a common denominator for all issues at the UR agenda. This common EU win-set for each issue was sufficiently narrow to be able to reach a common position. That the negotiations did not evolve within the EU level win-set means that while the evolution of the negotiations was still continuing within the win-set of some MSs, they evolved outside the win-set of one or more MSs. In other words, to expand the EU-level win-set and to provide the conclusion of the UR negotiations, the Commission had to expand the domestic win-sets of the MSs whose win-sets were narrow to cover the evolutions of the negotiations.

Difficulty to reach a common position between the MSs in international trade negotiations arises due to the fact that not all MSs have similar national interests and ideas as free trader or protectionist, and that private pressure groups representing the interests of an industry in the agenda of the negotiations prefer lobbying their national governments for the policies they wish to see pursued in the EU rather than making representations to the EU. While in a MS pressure groups representing a specific sector's interests have a very strong leverage because of the reasons mentioned in the first chapter under the subtitle of "pressure groups", in another MS pressure groups representing another sector's interests may be quite influential. Pressure groups representing the interests of an industry may be more influential in a MS than those representing the same industry in another MS. Therefore, the MS, which is under the pressure of such very influential interest groups, may not be able to give concession at the expense of the interests of the industry represented strongly. In such cases, a very serious problem arises between the MSs regarding the formation of a common position in international trade negotiations for the industry concerned.

In the UR negotiations such kind of problems were experienced with respect to some industries represented by pressure groups, which have strong leverage on some national governments like agriculture in France and textiles in Portugal. It may not be possible to reconcile the interests and, therefore, to reach a consensus on such industries unless the MS under strong domestic pressure 
obtains some concessions in favour of the interests of its industry concerned, as in the case of textile for Portugal and agriculture for France in the UR negotiations.

\section{3. Critique of a Pure Intergovernmentalist Approach to Common Trade Policy Making by the EU in International Trade Negotiations}

Pursuant to the procedure laid down in Article 113 of the Rome Treaty, proposals on trade policy issues are made by the Commission. In other words, power of initiative is in the hands of the Commission. However, the power of decision lies with the Council, which may approve, change or reject the Commission's proposals. The last say on trade policy matters, as in the other areas, belongs to the Council. Therefore, at first sight, trade policy making in the EU may appear to be a straightforward matter of intergovernmental politics and thus explained by the theory of intergovernmentalism. The intergovernmentalist theory is, however, incapable of providing an overall explanation of EU policy making in the CCP because it fails to theorise about the other institutional levels than the domestic and therefore cannot capture the dynamics of international bargains.

According to intergovernmentalist approach, first national positions on trade policy matters are decided within the governments of the MSs and then an agreed upon EU policy is reached by a process of bargaining among national representatives. Therefore, intergovernmentalists claim that the EU politics is the continuation of domestic politics by other means. This theoretical tradition builds on the assumption that states are the primary actors in the international system, and that interstate bargains reflect national interest and relative power. EU institutions are given the function of a regime, which will shape interstate politics by providing a common framework that reduces the uncertainty and transaction cost of interstate negotiations. According to the functional regime theory, EU institutions serve as a passive structure, providing a contractual environment conducive to efficient intergovernmental bargaining. They increase the efficiency of bargaining and, therefore, facilitate agreements that would not otherwise be reached. ${ }^{18}$

From an intergovernmentalist view, the participation of the EU in international trade negotiations will imply another stage in the intergovernmental policy making process. There will be three levels of analysis; the state level, the EU level and the international level. Governments first define a set of interests, then bargain among themselves in an effort to realise those interests through the negotiating directive issued to the Commission. The Commission will take part in the international negotiations, under tight control maintained by the Article 113 Committee, in order to realise the objectives laid down in the 
negotiating directive. These two games are linked by the Council ratification of the international agreement.

There are two parallel processes crucial to the international activity of the Union. The intra-EU game spills over or is projected into the international arena at the same time as external developments and external actors can become part of the EU bargaining process. ${ }^{19}$ The mutual dependence between the EU and the international political economy has been noted long ago by the European Court of Justice: "A commercial policy is in fact made up by the combination and interaction of internal and external measures, without priority being taken by one over the other. Sometimes agreements are concluded in execution of a policy fixed in advance, sometimes policy is defined by the agreements themselves." ${ }^{20}$ Moravcsik points out that "the question facing international relations theorists today is not whether to combine domestic and international explanations....., but how best to do so."21

The EU policy is not only shaped from an intergovernmental bargaining between the Union members, it is also shaped by initiatives deriving from external actors and the EU institutions. The MSs do, of course, play a central part in the policy development in the EU, but a narrow conception of bargaining among the MSs' governments would be misleading. Even though the EU's policy is rooted in the MSs, a comprehensive explanation of EU policy-making cannot be provided without analysing the origins of national preference formulation in an open and changing world economy.

Intergovernmentalist analysis, which adds one level to the other in a process taking place in successive stages, creates a division between the levels of analysis. Whereas the intergovernmentalist theory simply adds international institutional structures to the domestic policy-making, there is a need for a more integrated analysis of how these systems of governance relate to each other. Further studies on the EU trade policy-making must aim for an integrated approach where all institutional levels in the policy-making process are theorised about, as well as the interplay between these levels.

According to intergovernmentalist logic, the EU will have agreed on a common position prior to the international negotiations and the EU's bargaining power will be strengthened by the pure economic weight the EU carries relative to the other actors in the world trade system. In addition to the face value of the EU's economic strength, there are also alternative explanations of how the EU is capable to act as an active and deliberate actor towards other actors in the international system. Especially the role played by the Commission as the EU's chief negotiator and its ways to restructure the bargaining situations and to facilitate arrangements, which can secure an international agreement at the 
same time as ratification in the Council is ensured are quite important. Hence, instead of a pure intergovernmentalist model, the two-level bargaining model has to be modified to take into account the unique institutional structure of the EU.

\section{Negotiations on "Textiles and Clothing" Sector in the Ur As A Case Study}

Textiles and clothing (T\&C) has special importance for a sizeable number of developing countries' interest. Since production in this sector is labourintensive, the countries with low wage costs and a large working population, have significant advantages. Therefore, all countries in Asia and almost all countries in Latin America are exporters. Since the growth of the textiles sector in the developing world has been very dynamic, these countries have become a threat to the textiles industries of the industrialised world. Textiles sector is also of particular interest especially to some countries in the North since it has provided work for many hands. For example, in Portugal, one industrial job in three depends on the textiles or clothing industry. ${ }^{22}$

As a result, the industrialised countries had imposed limits on their imports of textiles in order to counter the threat from the South. Trade in this sector has been subject to import quotas and other trade restrictions for decades. The principal trade arrangement for international trade in T\&C was the Multi-Fibre Arrangement (MFA), which was established in 1973 as a temporary derogation from GATT rules. Under the MFA, countries concluded bilateral agreements with importers on import quantities. The trade policy of the EC on this sector was also formed by the bilateral agreements of the MSs with suppliers on import quantities under the umbrella of the MFA. The MFA provided for safeguard mechanisms in order to protect domestic industry in developed countries against a surge in imports. It had been renewed on three occasions. The last agreement that expired in 1991 stated that the ultimate objective of the agreement was the return of the T\&C sector to GATT rules. However, the UR negotiations on this sector proved that realisation of this objective was far from easy because of the pressure of domestic industry in developed countries. ${ }^{23}$

\section{1. Positions of the Key Players in the Negotiations}

Although not all the exporting developing countries suffered under the MFA system and, therefore, despite the diversity of their interests, they were able to put up a totally united front unlike the industrialised countries. They demanded the abolition of the MFA once and for all and the application of the normal GATT rules to trade in textile products. In other words, their aim was to integrate textiles sector into the GATT system as soon as possible and under favourable conditions. ${ }^{24}$ 
As importers, which made use of the MFA to restrict imports of textiles, this sector was even more important factor for the industrialised countries. Many of the industrialised countries that restricted imports through the MFA had, at the same time, strong export interests to pursue. For instance, the EC was a big exporter of textiles, with a strong interest in the US market. Governments of the industrialised countries knew that the MFA could not be maintained forever and it was inconsistent with their own declared economic philosophy and it set a damaging example for other sectors of trade. They had to convince their textiles industries, which were reluctant to acknowledge these realities. To be able to do that they tried to postpone the abolition of the MFA to gain time for adjustment of their industries and while accepting the necessity of eventual integration of this sector into the GATT system.

At the end of the consultations and bargaining between the North and the South under the auspices of the GATT, agreement had been reached on the negotiating objective to be set for $\mathrm{T} \& \mathrm{C}$ in the Punta del Este Declaration: "Negotiations in the area of textiles and clothing shall aim to formulate modalities that would permit the eventual integration of this sector into GATT on the basis of strengthened GATT rules and disciplines, thereby also contributing to the objective of further liberalisation of trade."25 Succeeding negotiations turned around discussions to formulate how trade in T\&C might eventually be brought back under the normal GATT rules, to determine what the "strengthened rules and disciplines" were to be, and whether they would be negotiated in the same group, or elsewhere, as part of the UR package.

With respect to the EC representing twelve states having different interests, to determine a common negotiating position and, therefore, to speak with a single voice regarding $\mathrm{T} \& \mathrm{C}$ sector had been far from being easy. This was because while free trader MSs were in favour of dismantling of the MFA system as supporters of multilateral trade liberalisation, southern Community MSs, especially Portugal, Italy and Greece were quite sensitive regarding textiles sector.

Together with Spain, Portugal was in midst of a difficult process of adjustment triggered off by membership of the EC in 1986. It was not keen to see multilateral liberalisation complicate even further the problems of economic and social adjustment. Its T\&C industry accounts for one-third of the country's manufacturing employment and one-third of its manufacturing exports. It forms an extreme case in Southern Europe. Due to Portugal's less diversified industrial sector, T\&C industry is bigger proportion of Portuguese manufacturing than it is in Spain or even Italy although both of them have larger T\&C sectors. The sector is concentrated in a few areas that rely entirely on the textiles industry. ${ }^{26}$ The Portuguese government was under intensive pressure by the quite influential 
interest groups representing interests of textile producers. Therefore, this sector is of vital interest to Portugal.

Paemen and Bensch point out that Portugal's concerns about the problems of economic and social adjustment shared by Greece which had joined the EC on 1 January 1981 but still found itself in a phase of transition. ${ }^{27}$ Although Greece could not claim that its own textiles sector carried as much economic weight, it strongly disliked the idea of having to open up its market to competition from low-wage countries. Textile was obviously Italy's prime concern as well since it has large $\mathrm{T} \& \mathrm{C}$ sector. Its $\mathrm{T} \& \mathrm{C}$ sector accounts 10 percent of manufacturing production and 13 percent of employment.

Actually these countries did not want to lose protection of their T\&C sectors from competition with low-wage countries both in their domestic market and in European markets to which free access provided by full EC membership. However, after consultations and negotiations between the Council and the Commission, and within the Council, a common negotiating position regarding T\&C sector was able to be determined. After the Council decided on $19 \mathrm{March}$ 1985 on the basis of a communication by the Commission to support a new round of GATT trade negotiations, the Commission started to work on Community's negotiating position papers covering the potential agenda of the UR negotiations by discussing both with the other contracting parties to the GATT and the Council simultaneously. By the end of May 1986, the Commission produced a position paper in the light of these discussions and submitted it to the Council as a communication on the "Overall Approach" to the new GATT round. The Council reached a consensus to welcome the Commission's communication in its meeting on 16 and 17 June 1986. Overall Approach which is the basic negotiating mandate for the EC set out broad objectives and priorities of the EC regarding the issues in the UR negotiations.

Although Southern Community MSs like Italy, Greece and especially Portugal did not want removal of protectionist MFA system, eventual integration of T\&C sector into the GATT was determined as the EC's negotiating objective in the UR. However, even though the overall approach did not refer to the need to strengthen the rules of the GATT, this was determined as a precondition for trade liberalisation at the beginning of the negotiations. ${ }^{28}$ The Community said that it would accept the phase-out of the MFA restrictions only on the clear condition that this would and go hand in hand with the improvement of access for European exporters to the markets of all countries that are major producers of T\&C products. Additionally, new GATT rules and disciplines in this sector would have to level the conditions of competition among producers in developed and developing countries. ${ }^{29}$ Since the MSs, who did not want to dismantle MFA as importers, were exporters as well, internal consensus could be reached 
owing to these conditions agreed as the negotiating position of the EC. In other words, the twelve MSs with different policy objectives and interests were able to agree on a common denominator for this issue.

However, the UR negotiations proved that maintaining this initial internal consensus was more difficult than determining it since maintaining an internal consensus between the MSs subjected to, first of all, the satisfactory evolution of the multilateral negotiations.

\section{2. Evolution of the Negotiations and Problems Regarding Internal Cohesion in the $\mathrm{EC}$}

In the UR negotiations on T\&C sector, the debates were split along NorthSouth lines. Although the developed countries were not able to put up a totally united front like developing countries, they had shared interests and, therefore, their negotiating objectives were in the same line. According to the importing industrialised countries, since the Punta del Este Declaration ordered them to formulate modalities that would permit the eventual integration of this sector into the GATT, the use of the conditionality is very important. Because the structural crises which had brought the MFA into being was still not over, there could be no question of eliminating the MFA until the international trade had been put on a healthier footing for all. ${ }^{30}$

At the beginning of the negotiations, especially the EC, as the key player in the importers' bloc, strongly stressed that liberalisation would require strengthening of all GATT rules and disciplines, and a general opening of markets. However, this emphasis on non-MFA issues was rejected by developing countries which insisted that such matters were for negotiation elsewhere in the Round. ${ }^{31}$

T\&C sector was one of the four areas where no agreement could be reached in Montreal. Therefore, it was decided to extend the deadline for these four areas until April 1989 and to ask the director-general of GATT, Arthur Dunkel, to hold high level consultations on these in view of reaching agreements. ${ }^{32}$ At the second meeting in April 1989 to conclude the Mid-Term Review, initial internal cohesion, which was apparently fragile and impotent, broke down. Not only Italy and Portugal but also Spain, Belgium, France, Greece and Ireland voiced strong criticism of Dunkel text at a meeting of the Article 113 Committee. They complained that the text lacked balance in that it unilaterally stated the aim of doing with the MFA but was silent on the question of strengthening rules and disciplines. Dunkel did not want to revise his text since he thought that the amendments suggested by the EC would make the text unacceptable to the developing countries. The Commission began to put pressure on Dunkel 
to revise it. At the end, Dunkel had to revise his text and tried to improve the balance of the text by inserting a reference to reinforced rules and disciplines. Except Italy, most MSs accepted the revised text. At the same time, on the multilateral level, the Commission was trying to persuade the developing countries to accept Dunkel's amendments. They agreed only when the success of the other three negotiating groups was made official since they could not afford to take the blame for the failure of the mid-term review. Meanwhile, in addition to Italy, Portugal refused to agree the text as well. ${ }^{33}$

They objected to the wording on $\mathrm{T} \& \mathrm{C}$ and claimed that the Commission had exceeded its negotiating mandate. The issue was resolved since both were overruled by the other MSs in the Council. The Council reaffirmed its support for the Commission stand and reiterated the link between the UR negotiations and $\mathrm{EC}$ policy in this sector. ${ }^{34}$ However, the problem for the EC regarding maintaining internal cohesion was not able to get rid of completely. Depending on the evolutions of the negotiations, the EC experienced this problem more intensively at the later stages of the negotiations.

During the following phases of the UR, importers, especially the EC, criticised the proposals made by the developing countries as unrealistically ambitious, and because they did not deal with GATT-inconsistent restrictions, or with strengthening GATT rules and disciplines. While the exporters pushed for integration and liberalisation rules that would remove all barriers smoothly over five-year transition period, the importers which were not prepared to force rapid adjustment on their domestic industries preferred as long a transition as possible (fifteen years) even at the cost of major adjustments when the MFA disappeared. The insistence of the importers in general and of the EC in particular on linking MFA liberalisation with market opening by the exporters as well was highly controversial since exporters maintained that strengthening the general GATT rules and disciplines affecting trade in this sector was matters for discussion elsewhere in the Round. Moreover, exporters also remained opposed to the EC's proposal on a verification mechanism. They thought that this mechanism would subject them to constant threat that the liberalisation process would be halted. This mechanism would establish a process by which the progress of individual countries from the MFA to full integration would be subject to review of how they were fulfilling the commitments.

As a reaction to these unsatisfactory evolutions in the negotiations, Portugal voiced its intensive criticism on uncertainty over the outcome of the UR trade talks. Portugal was vehemently opposed to a full and abrupt liberalisation of the textile trade without a parallel strengthening of GATT rules and disciplines. Officials and manufacturers in Portugal thought that sudden liberalisation would be disastrous for Portugal and for its textile industry without guarantees 
over fair competition and reciprocity of access to markets. According to Portugal, there should be a fifteen-year transition period staggered in three stages and closely monitored and controlled by a permanent committee made up of representatives from the EC, the US, developing countries and the European textile industry. Additionally, an agreement would have to be backed by a system of penalties. ${ }^{35}$

Although it was not alone in Europe in complaining on the possible impact of liberalisation, the weight of the textile industry in its economy was far greater than for any of its EC partners. Almost 70 percent of Portugal's textiles and clothing exports were going to EC countries. Opening wide Europe's doors to cheap imports from newly industrialised countries in Asia, or to low cost producers in north Africa, south America and eastern Europe, would most probably exacerbate the problems of its $T \& C$ industry which was already in crises. ${ }^{36}$

\section{3. The Final Stage of the Negotiations and Reaching Internal Consensus}

The final bargaining for $\mathrm{T} \& \mathrm{C}$ took place during the first half of December 1991 and they could agree on the results to be incorporated in the Draft Final Act. The phase-out period was agreed as ten years starting with the expected entry into force of the Round as whole, and divided into three phases of three, four and three years respectively. Additionally, it was agreed that all countries would abide by GATT rules and disciplines to improve market access, ensure fair and equitable trading conditions and not discriminate against the textiles sector in their import policy. However, any explicit link was not established between compliance with these assurances and the MFA phase-out. In general, the strengthening of market access, rules and disciplines was sought in the other UR negotiating groups rather than via the textile negotiations ${ }^{37}$ Therefore, the Portugal thought that the textile agreement would not provide sufficient guarantee over fair competition and reciprocity of access to markets. For example, according to Portugal, in the case of India and Pakistan, the market opening commitments were insufficient.

Furthermore, phase-out period was determined shorter than what Portugal had expected. Portugal argued that the results of the T\&C negotiations were unbalanced in terms of the burden sharing of sacrifices within the Community. While its industry would be obliged to bear a disproportionate and untenable cost, the EC as a whole and more specifically the northern MSs would obtain important gains from the conclusion of the Round. Therefore, during the final phase of the Round, Portugal expressed the formal position that the results of 
the negotiations could not be regarded as acceptable. On the eve of the European Council meeting on 10-11 December 1993, it informed the other MSs that it could not accept the conclusions of the UR since its vital interests were at stake. ${ }^{38}$

To persuade Portugal not to veto the approval of the UR's Final Act in the Council and, therefore, not to jeopardise the conclusion of the Round, the Commission initiated a proposal of 400 million ECU to help modernise the Portuguese textiles industry. After the Council had approved this proposal, Portugal decided not to veto the UR conclusions. Therefore, a consensus could be reached to approve the Round's Final Act. ${ }^{39}$

\section{Conclusion}

On 15 December 1993, the Council of the EU gave its political approval to the results of the UR. However uncertainty about the approval of the results remained great since internal consensus on textiles and agriculture, which was necessary to secure the approval, could not be achieved until the very last moment.

Since maintaining internal cohesion between the MSs required, first of all, the satisfactory evolution of the multilateral negotiations for all them, the role of the Commission as chief negotiator of the Community was quite important. During the negotiations, each of the MSs had to be assured that its interests were being appropriately defended by the Commission. On the one hand, the Commission tried to attain a consensus with the other negotiating parties acceptable for all MSs. On the other, it worked to maintain internal cohesion within Community especially in cases that it could not convince the third countries for an acceptable agreement to all MSs. The Commission tried to persuade its negotiating colleagues from the third countries to accept its negotiating objectives. Even in some cases that it could succeed this generally by exchanging concessions with its negotiating partners, this was not enough to satisfy interests of some MSs. In these situations, either those states were overruled by the other MSs in the Council or the Commission had to propose side-payments to alter the outcomes otherwise expected when those states threaten to invoke vital interests.

In the areas of both textiles and agriculture, balanced exchanges of concessions between the Community and its negotiating partners were not always sufficient condition to guarantee the necessary support of all MSs for the Round's outcome. As Portugal claimed, the Round was expected to have widely different consequences within the EC, depending on the economic and social conditions in each MS. Therefore, the Commission needed to propose substantial internal 
compensatory arrangements at the end of the Round for the Portuguese textiles industry and the CAP to bring the Round to a positive close.

In the case of textiles, all MSs could find a lowest common denominator for their different sized win-sets to constitute Community level win-set at the beginning of the UR. However, when the negotiations did not evolve completely within the EC level win-set because of balanced exchanges of concessions between the Community and its negotiating partners, and because of the dependency of the negotiations on the negotiations of other issue areas like services and intellectual property rights, they evolved outside the win-set of Portugal as well. In other words, although the other Southern Community MSs could be convinced, internal cohesion of the EC could not be maintained because of Portugal's high sensitivity to this sector. To be able to reach internal consensus, in other words, to expand the EC-level win-set for the aim of securing the conclusion of the UR Final Act, the Commission had to expand domestic win-set of Portugal. Portugal's win-set was narrow enough to cover the evolutions of the negotiations.

Since the costs of the possible agreement concentrated on a specific group (textile producers), this concentrated group that was disadvantaged by the agreement became both intransigent and influential opponents of the UR textiles negotiations. Additionally, the losses of the possible agreement were so clear and certain for Portugal's textiles sector that Portugal could claim decisively its sector to be damaged by multilateral deals. Therefore, the Commission, which acted simultaneously at all three levels of the UR, had to propose substantial side-payment to the Council to expand Portugal's domestic winset to attain internal consensus. After the Council had approved a special Community action of 400 million ECU, internal consensus necessary for the approval of the Round's Final Act could be reached.

In view of the remaining differences between the MSs on international trade policy and of the EU's prospects regarding enlargement, it is likely that the difficult process of providing internal consensus will take place in the next WTO round, Millennium Round. The EU's credibility as a meaningful player in the Millennium Round will depend primarily on its ability to overcome the current threat of fragmentation. 


\section{Endnotes}

1 Anna Murphy, The European Community and the International Trading System, Vol. 2, Brussels: Centre for European Policy Studies, 1990, 122.

2 M. Hodges and S. Woolcock, "The European Union in the Uruguay Round: The Story Behind the Headlines" in H. and W. Wallace (Eds.) Decision Making in the European Union, 1996, 302.

3 Rohini Acharya, Making Trade Policy in the EU, The Royal Institute of International Affairs, Discussion Paper 61, 1995, 26.

4 Peter L. H. Van den Bossche, "The EC and the Uruguay Round Agreements" in J. H. Jackson and A. O. Sykes (Eds.) Implementing the Uruguay Round, Clarendon Press, Oxford, 1997, 25.

5 Murphy, Vol. 2, 39,40.

6 Bossche, 59.

7 Hodges and Woolcock, 305.

8 Acharya, 13.

9 D. Greenaway and R. C. Hine, "Trade Policy and Protection in the European Community" in Open Economies Review, Vol.4, No. 4, 1993, 434.

10 Robert D. Putnam, "Diplomacy and Domestic Politics: The Logic of Two-Level Games" in International Organisation, Vol. 42, No. 3, Summer 1988, 434.

11 Ibid. 434-436.

12 Robert D. Putnam, "Two-Level Games: The Impact of Domestic Politics on Transatlantic Bargaining" in H. Haftendorn and C. Tuschhoff (Eds), America and Europe in an Era of Change, Westview Press, Oxford, 1993, 71.

13 Andrew Moravcsik, , "Integrating International and Domestic Theories of International Bargaining" in P. B. Evans, H. K. Jacobson and R. D. Putnam (Eds.) Double-Edged Diplomacy: International Bargaining and Domestic Politics, University of California Press, 1993, 17.

14 Ibid., 23-24.

15 Ibid., 25.

16 Ibid., 26, 27. 
17 Putnam, 1993, 80.

18 Andrew Moravcsik, "Preferences and Power in the EC: A Liberal Intergovernmentalist Approach" in Journal of Common Market Studies, Vol. 31, No. 4, December 1993, 508.

19 Michael Smith, "The EU, Foreign Economic Policy and the Changing World Arena", in Journal of European Public Policy, 1:2 Autumn 1994, 296.

20 The quote is taken from the ERTA (Europe Road Agreement), Case (22/70): Commission of the EC v. Council of the EC, (1971) European Court Reports, 263; cited in Maas (1976:384).

21 Moravcsik, 9.

22 Hugo Paemen and Alexandra Bensch, From the GATT to the WTO: The European Community in the Uruguay Round, Leuven University Press, 1995, 39,40.

23 Anna Murphy, The European Community and the International Trading System, Vol. 1, Centre for European Policy Studies, Brussels, 1990, 131.

24 Paemen and Bensch, 40.

25 Ministerial Declaration, 20.9.1986, 5,6.

26 Cristina Corado and Joao Ferreir Gomes, "Adjusting to Trade Liberalisation: The Case of Portugal", in B. Navaretti, R. Faini and A. Silberston (Eds.) Beyond the Multifibre Arrangement: Third World Competition and Restructuring Europe's Textile Industry, OECD, Development Centre Documents, 1995, 61, 62 .

27 Paemen and Bensch, 46.

28 Murphy, Vol. 2, 115.

29 Youri Devuyst, "The European Community and the Conclusion of the Uruguay Round", in C. Rhodes and S. Mazey (Eds.) The State of the European Union Vol.3: Building a European Polity, Lynne Rienner, 1995, 459.

30 Paemen and Bensch, 117.

31 John Croome, Reshaping the World Trading System, World Trade Organisation, $1995,109$.

32 Finn Laursen, "The EC, GATT, and the Uruguay Round" in L. Hurwitz and C. Lequesne (Eds.) The State of the European Union Vol.1: Policies, Institutions and Debates in the Transition Years, Lynne Rienner, 1991, 378. 
33 Paemen and Bensch, 142, 143.

34 Murphy, Vol. 2, 122.

35 Blumm, Patrick "World Trade News: Portugal Fears Textiles Will Fall Victim to GATT Deal", in Financial Times, 16 November 1990.

36 Ibid.

37 Croome, 310-312.

38 Devuyst, 459.

39 Press Release of the Continuation of the $1726^{\text {th }}$ Meeting of the Council General Affairs, 15 December 1993 (Brussels: Council of the European Union, 15 December 1993). 